\title{
A TeOlogia Negra da Libertação eM JAMES CONE: aspectos de sua hermenêutica contextual a partir de "O Deus dos Oprimidos" (1975)
}

\author{
THE BLACK THEOLOGY OF LIBERATION IN JAMES CONE: \\ aspects of its contextual hermeneutics based on \\ "God of the Oppressed" (1975)
}

\section{Joe Marçal Gonçalves dos Santos * Charlisson Silva de Andrade **}

\begin{abstract}
RESUMO
O artigo trata da compreensão de James Cone de sua Teologia Negra da Libertação (TNdL), com o objetivo de destacar sua definição hermenêutica a partir de pontos convergentes e divergentes com a teologia contemporânea. $\mathrm{Na}$ introdução, situamos historicamente o surgimento da TNdL; seguimos com uma descrição do sujeito dessa teologia em seu contexto, condição existencial e política; na terceira seção, tratamos do papel do/a teólogo/a negro/a, tal como James Cone o compreende; em seguida, descrevemos as fontes da TNdL, chamando a atenção para seu caráter orgânico e comunitário. Nas conclusões, destacamos implicações da compreensão hermenêutica da teologia na TNdL.
\end{abstract}

Palavras-chave: Hermenêutica. Teologia. Sociedade. Racismo.

\section{ABSTRACT}

The article deals with James Cone's understanding of his Black Theology of Liberation, with the aim of highlighting the hermeneutic definition of this theology, from convergent and divergent points in relation to contemporary theology. In the introduction, we present the emergence of Black Theology of Liberation in its historical context; then, we describe the subject of this theology in its context under existential and political aspects; in the third section, we deal with the role of black theologians, according to James Cone's understanding; finally, we define the sources of Black Theology of Liberation, paying attention to their organic and community characteristics. In the conclusions, we highlight some implications of the hermeneutic understanding of theology in Black Theology of Liberation.

Keywords: Hermeneutics. Theology. Society. Racism.

\section{INTRODUÇÃO}

A Teologia Negra da Libertação (TNdL) é uma teologia cristã que ganha corpo no decorrer do século XX, a partir da experiência afro-diaspórica, constituindo-se em um complexo soteriológico-escatológico determinado pela ideia de libertação $e$

\footnotetext{
* Doutor em Teologia com pós-doutorado em Antropologia Social. Atualmente, professor adjunto do Núcleo de Ciências da Religião da Universidade Federal de Sergipe. E-mail: jmgsantos@yahoo.com.br

** Licenciado em História pela Universidade Federal de Sergipe. Atualmente, mestrando em Ciências da Religião na Universidade Federal de Sergipe e Bolsista CAPES/DS. E-mail: lenodeandrade@gmail.com
} 
justiça em relação ao povo negro. Trata-se de uma hermenêutica teológica antirracista, na qual a fé está organicamente vinculada às condições materiais de existência. Nela, busca-se uma compreensão dos textos bíblicos que efetivamente responda à realidade da vida da comunidade negra, objetivando, por meio de valores cristãos, uma transformação concreta de tal realidade. Portanto, trata-se de uma teologia engajada, que se situa criticamente em uma sociedade marcada pela segregação racial e heranças culturais e sociais da colonização e da escravidão, e que, diante desse cenário, se empenha por processos de transformação.

A reflexão teológica negra nos Estados Unidos surge na segunda metade dos anos 1960, hegemonicamente protestante, inspirada na tradição da experiência religiosa na Igreja Negra e a histórica resistência negra contra a escravidão, tendo como pano de fundo a luta do Movimento dos Direitos Civis e o Movimento de Poder Negro $^{1}$. Envolvida com os acontecimentos da época, a Teologia Negra norteamericana é pensada em consonância com as demandas sociais e políticas da comunidade negra (CONE, 1983; DUNAWAY, s.d.; GIBELLINI, 1998).

Em uma sociedade marcada por um cristianismo branco e racista, tal como denuncia a teologia negra, uma resposta negra foi construída dentro da própria religião cristã. Uma interpretação bíblica que nega uma hermenêutica neutra, relacionava o sofrimento de Jesus Cristo ao sofrimento dos negros, numa perspectiva emancipadora, em que um Cristo negro é um Cristo que age no mundo ao lado dos oprimidos (GRANT, 1997).

O teólogo negro estadunidense James Cone (1936-2018) é pioneiro na exposição sistemática da teologia negra através da publicação de duas obras, Teologia negra e Poder Negro (1969) e Teologia negra da libertação (1970)² (CONE, 1983; GIBELLINI, 1998), tornando-se não só o precursor, mas também, com suas

\footnotetext{
${ }^{1}$ O Movimento dos Direitos Civis teve origem em meados da década de 1950, tendo como uma das principais características a luta pela abolição da segregação racial, o caráter reformista, integracionista e a estratégia da não-violência. Entre as principais lideranças a figura do pastor batista Martin Luther King Jr. O Movimento de Poder Negro, surgido em meados da década de 1960, é associado a ativistas como Malcolm X e Stokely Charmichael, tendo um caráter revolucionário, separatista e adepto da violência revolucionária.

2 "É interessante notar que Teologia negra da libertação (1970) de James Cone é o primeiro tratado sistemático de 'teologia da libertação' e precede Teologia da libertação (1971) de Gustavo Gutiérrez, que continua sendo o primeiro tratado sistemático da teologia latino-americana da libertação (se bem que Gustavo Gutiérrez tivesse anteriormente produzido o ensaio Para uma teologia da libertação, 1968-1969, que entretanto não atinge ainda a sistematicidade do tratado)" (GIBELLINI, 1998, p. 397). Apesar da defesa de Gibellini a respeito do pioneirismo da Teologia Negra enquanto uma teologia da libertação, devemos ainda notar que, em 1969, Rubem Alves publicava a sua tese de doutorado, originalmente intitulada Towards a Theology of Liberation, posteriormente alterada para $A$ Theology of Human Hope.
} 
publicações posteriores, a principal referência dessa expressão teológica, que não ficaria circunscrita à América do Norte.

Traço básico desta teologia, portanto, é sua constituição marcada pela interpretação da mensagem cristã a partir das demandas de comunidades afrodiaspóricas subjugadas pelo racismo e mazelas sociais herdadas da colonização. No que segue, nossa proposta é afirmar a TNdL entre as teologias situadas na "virada hermenêutica", tal como sintetiza Claude Geffré em Crer e interpretar (GEFFRÉ, 2004), cujas bases são lançadas nas críticas à teologia liberal e a Kulturprotestantismus que, por sua vez, se desenvolvem desde o século XIX, se acirram no pós-Primeira Guerra e no cenário em torno da Segunda Guerra. Autor emblemático, nesse sentido, é Paul Tillich, com o qual vamos dialogar em razão de sua definição hermenêutica de teologia, que ganha síntese em sua Teologia sistemática (TILLICH, 2005). Nessa análise, destacaremos argumentos embasados no deslocamento da metafísica a uma ontologia histórica e existencial, bem como a condição contextual de tal reflexividade teológica, que, no caso da TNdL, se radicaliza na corporeidade como território elementar do pensar e discursar teológico. Isto é, ao assumir esse princípio ontológico, inevitavelmente a condição histórica, política e existencial marcada pela escravidão e segregação racial determinará epistemologicamente a hermenêutica teológica negra.

A estrutura do artigo se valerá, especificamente, de $O$ Deus dos oprimidos 3 , de James Cone, originalmente publicado em 1975, com atenção especial aos dois primeiros capítulos, onde destacaremos aspectos teórico-metodológicos implicados na compreensão de teologia desenvolvida pelo autor. Iniciaremos tratando da importância da experiência de vida do teólogo negro para a sua formação teológica e sua perspectiva epistemológica. Em seguida, abordaremos o papel que James Cone atribui ao teólogo negro em seu fazer teológico. Por fim, apresentaremos as principais fontes da teologia negra, segundo James Cone.

3 Além de ser uma das obras pioneiras da reflexão teológica negra (CONE, 1983), o livro preenche uma lacuna deixada por textos anteriores do próprio James Cone, que não demonstraram com clareza o significad o da Igreja Negra, em particular a Igreja Metodista Episcopal Africana Macedônia, e a marca dessa comunidade em sua reflexão teológica (CONE, 1985). 


\section{EXPERIÊNCIA DE VIDA DO TEÓlOGO: UM ELEMENTO DE SUA FORMAÇÃO TEOLÓGICA}

Para James H. Cone (1936-2018), a história pessoal do teólogo é o fator mais importante na formação da metodologia e conteúdo de sua perspectiva teológica, que implica no seu vínculo existencial com um determinado contexto sociopolítico. Com isso, Cone defende que a interpretação teológica e o modo de construí-la enquanto narrativa são determinadas por subjetividades situadas em realidades concretas, o que o levará à crítica da suposta universalidade da teologia tradicional europeia e norte-americana, em outras palavras, a teologia ocidental branca. Nesse ponto, Cone está em sintonia com sua geração, que situa o fazer teológico, seu discurso e sua tradição nas condições históricas de sua produção, assumindo a hermenêutica não apenas como um momento metodológico, mas como condição da própria teologia.

Com isso, estamos situando a teologia de Cone na virada hermenêutica encabeçada pela filosofia no século passado, como um desdobramento da crítica à metafísica do pensamento moderno. Hans-Georg Gadamer, em Verdade e método (1999), demarca significativamente esse deslocamento crítico em relação à tradição filosófica cartesiana, privilegiando a experiência simbólica para o conhecimento do humano e, na esteira de Heidegger, toma a própria linguagem como "horizonte de uma ontologia hermenêutica" (GADAMER, 1999, p. 639s). Com Paul Ricoeur, a crítica da virada hermenêutica é incrementada com as "suspeitas" freudiana, marxiana e nietzschiana. As objetivações históricas da linguagem e da criatividade humana, especialmente a literatura, tornam-se objeto de uma interpretação crítica. A realidade desejada ou as "proposições de mundo" (RICOEUR, 1977), com toda sua riqueza e ambiguidade, é o que interessa a Ricoeur, porque, segundo ele, é por meio das representações simbólicas que o humano se revela - daí o lugar da religião em sua hermenêutica simbólica (GROSS, 1999). Nesse sentido, Ricoeur recupera algo apontado por Wilhelm Dilthey (1999) em um escrito de 1900, quando chama atenção para a qualidade teológica do legado hermenêutico que está na base epistemológica das ciências humanas (Geisteswissenschaft). Não poderia ser diferente que, ao longo do século XX, essas inflexões críticas à modernidade repercutissem na reflexão teológica. 
É assim que Claude Geffré (2004, p. 36, 37 - grifo do autor), valendo-se de Ricoeur, pondera que "adotar um modelo hermenêutico em teologia não significa que não há mais dogma, mas é tomar como ponto de partida um texto", a fim de "discernir os elementos fundamentais da experiência cristã e dissociá-los das linguagens nas quais esta experiência foi traduzida". Tarefa que "só é possível [realizar] a partir de nossa situação histórica e de nossa experiência atual da existência humana”. Na mesma linha, Paul Tillich insistira nesse modelo de teologia ao longo de sua vida, ao definí-la como teologia da cultura, revisando a própria noção de apologética a partir da condição hermenêutica e contextual de todo ato do espírito humano. Em sua Teologia sistemática, isso se sintetiza no método de correlação como o modus operandi de toda teologia (TILLICH, 2005, p. 21, 74-79). E mesmo que essa correlação se dê entre "situação cultural" e "mensagem", a qualidade existencial da teologia necessariamente implica a pessoa do/a teólogo/a (TILLICH, 2005, p. 27-28). É por isso que James Cone, em O Deus dos oprimidos, faz questão de se autobiografar: não como uma simples informação marginal a seu discurso, mas como condição de sua teologia, a fim de justificar a formação religiosa e intelectual que o leva a desenvolver uma teologia na perspectiva do negro. A novidade, contudo, está justamente nas condições dessa existência: tão piedosa e cristã quanto a de um homem negro nascido no interior dos EUA em meados do século passado, com tudo o que isso implica em termos morais e políticos. Em suma, sob a repercussão da virada hermenêutica na teologia, o que sublinhamos é que as condições históricas e contextuais constituem sujeitos e a relação destes com uma realidade/mundo; isto é, sintetizam corpos, seu lugar no mundo e a própria constituição deste mundo, colocando o estatuto ontológico deste e a base epistemológica de sua narrativ a sob as bases específicas de um corpo negro, escravizado, segregado e objeto de racismo, tornando-o um lugar de interpretação e de fala próprio.

Nosso autor relata que seu nascimento ocorreu na pequena cidade de Fordyce, em Arkansas. Porém, com apenas um ano de idade, mudou-se com a família para Bearden, uma pequena comunidade marcada pela segregação racial, com a população de maioria branca. É nessa comunidade que Cone crescerá e desenvolverá suas primeiras reflexões, constatando as contradições da sociedade em que vivia: "duas importantes realidades formaram minha consciência: a experiência da Igreja Negra e o significado sociopolítico do povo branco" (CONE, 1985, p. 9). 
Cone descreve a sua experiência na Igreja Negra como uma experiência de fortalecimento de esperanças em busca de um mundo transcendente àquela realidade marcada pelo racismo, onde era afirmado o seu pertencimento à comunidade negra:

A Igreja Negra introduziu-me na essência da vida como expressa no ritmo e sentimentos do povo negro em Bearden, Arkansas. Na Igreja Metodista Episcopal Africana Macedônia, encontrei a presença do Espírito Divino, e minha alma se comoveu e se encheu de uma aspiração por liberdade. Através da oração, do cântico e do sermão, Deus fez frequentes visitas à comunidade negra de Bearden e tranquilizou o povo com o seu interesse pela felicidade desse povo e com o seu desejo de levá-lo seguramente ao lar. O lar era frequentemente identificado com o céu - aquela realidade "sobrenatural" que está fora do alcance das limitações apavorantes deste mundo. Era aquele lugar do "outro lado do Jordão", "além da margem de rio abaixo", onde as ruas são de ouro e os portões são de pérola. O lar era aquela realidade escatológica onde os oprimidos "deporiam o pesado fardo", cantando e gritando, porque "não haveria ninguém lá para expulsá-los". Todo domingo, os irmãos e irmãs negros de Macedônia experimentavam uma amostra de seu "lar na glória", quando o Espírito de Deus visitava o culto deles, e eles respondiam com gratidão e humildade, cantando alegremente (CONE, 1985, p. 9).

James Cone respondeu à experiência da Igreja Negra oferecendo-se como membro em Macedônia quando tinha dez anos de idade, e entrando no ministério com dezesseis anos. Porém, lamenta pela experiência da Igreja Negra não ter sido a única experiência na cidade onde cresceu. Percebia que o discurso dos cristãos brancos legitimava a opressão dos negros, articulado com seus interesses sociais, políticos e econômicos:

O povo branco fez tudo dentro dos limites do seu poder para definir a realidade negra, para dizer-nos quem nós éramos - e a sua definição, naturalmente, não se estendeu a mais do que a seus interesses social, político e econômico. Eles tentaram fazer-nos crer que Deus criou o povo negro para ser escravo do povo branco. Por esta razão, esperava-se que nós, negros, tivéssemos prazer em arar os seus campos, limpar as suas casas, aparar a sua grama e trabalhar em suas serrarias. E quando mostramos sinais de desprazer com o nosso assim chamado estado eleito e inferior, eles nos chamaram de "negros arrogantes" e rapidamente tentaram nos colocar em nosso "lugar" (CONE, 1985, p. 10).

Apesar do racismo, a afirmação da humanidade do negro dava-se no tempo e no espaço sagrados da Igreja Negra, onde os negros podiam vivenciar a sua identidade, afirmando serem o que eram, experimentando antecipadamente a liberdade que desejavam alcançar e vendo em Jesus o sentido de vida contra a opressão: 
Decorridos os seis dias da semana nos quais eles eram considerados como nada pelos dirigentes da sociedade branca, no sábado, o sétimo dia da semana, o povo negro ia à igreja a fim de experimentar uma outra definição de sua humanidade. Como Maria Madalena no túmulo, procurando o corpo de Jesus, o povo negro de Bearden ia à igreja procurar Aquele que disse: "Eu sou o caminho, a verdade e a vida" (Jo 14,6). E, como Maria, eles estavam contentíssimos por achá-lo vivo e presente na igreja. (...) Aqueles seis dias de rodar e tratar com o povo branco sempre levantavam a ansiosa questão de se a vida era um viver digno. Mas, quando os negros iam à igreja e experimentavam a presença do Espírito de Jesus entre eles, concordavam que ele dava um significado às suas vidas, o qual não podia ser arrancado pelo povo branco (CONE, 1985, p. 21-22).

Essa experiência de vida, onde cristãos negros eram segregados por brancos que também se consideravam cristãos, foi fundamental para o pensamento teológico negro de James Cone. Naquele contexto, perdia-se o sentido de distinguir e distanciar a racionalidade teológica da vivência e participação dos símbolos e narrativas cristãs. Ao perceber que a comunidade negra tinha preocupações distintas das dos brancos, Cone deduzia questões que a Teologia Negra deveria assumir, que não eram respondidas pela teologia tradicional:

Minhas reflexões teológicas são inseparáveis da experiência de Bearden. Eu digo com Claude McKay que "aquilo que escrevo é expelido de meu sangue" e do sangue dos negros de Bearden e de qualquer outro lugar que vê o que eu vejo, sente o que eu sinto e ama o que eu amo. Isso é a razão pela qual a Teologia Negra difere em perspectiva, conteúdo e estilo da tradição teológica ocidental transmitida desde Agostinho até Barth. Minha teologia não será a mesma que as de meus colegas brancos do Union Theological Seminary, porque nossa experiência é diferente (CONE, 1985, p. 11).

Para compreender a percepção de James Cone, valem algumas notas sobre tal contexto. Bearden está situada no estado de Arkansas, geograficamente localizado no sudeste dos Estados Unidos e historicamente ligado ao sul, região que até o século XIX foi economicamente marcada pelas plantations de algodão, em que a mão de obra era composta por negros escravizados. Após a Guerra de Secessão (1861-1865), em que os estados do norte, favoráveis à abolição da escravatura, derrotaram os confederados (estados do sul), favoráveis à manutenção do regime escravista, a escravidão foi abolida em todos os estados. No entanto, na primeira metade do século XX, a população negra continuava marginalizada. O racismo era institucionalizado por políticas de segregação racial. As leis segregacionistas, conhecidas como "as leis 
de Jim Crow", vigoraram entre o final do século XIX e a década de 1960 do século XX. Estas leis se caracterizavam por promover a segregação racial em espaços públicos, incluindo escolas e transportes coletivos (SANTANA, 2017, p. 10). Nesse contexto, as igrejas cristãs também refletiam a política segregacionista, havendo igrejas específicas para brancos e outras para negros.

A epistemologia da Teologia Negra, bem como a ontologia em que ela se assenta, são indissociáveis da realidade concreta dos negros. Cone aprendera com seus mestres que toda teologia é condicionada por uma realidade concreta; mas evoca sobre essa relação uma realidade particular, na diferença de sua condição étnica sob a negação racista e a violência segregatória reiterada pelo próprio cristianismo. Nessa diferença incide a experiência que Tillich define como "choque ontológico", quando a "ameaça do não-ser (...) se apodera da mente (... ) e se experiencia o lado negativo do mistério do ser" (TILLICH, 2005, p. 126). Ora, a reivindicação de Cone por uma teologia negra se desdobra a partir da percepção e denúncia de uma estrutura social que, para a comunidade negra, institucionalizava a “ameaça do não-ser”. Por isso, compete à Teologia Negra não só constatar esse fato, mas assumí-lo profeticamente como indispensável para a transparência dos seus objetivos.

Junto da vivência de racismo e a busca pela liberdade e afirmação existencial através da Igreja Negra, a efervescência de movimentos negros nos Estados Unidos da década de 1960, a exemplo do Black Power, foi crucial para James Cone, que lançaria seu primeiro livro de Teologia Negra no final dos anos 1960:

Porque eu vivi a experiência de Bearden, não posso separá-la de minha perspectiva teológica. Eu sou um teólogo negro! Portanto, devo abordar o assunto da teologia à luz da Igreja Negra e daquilo que isso significa numa sociedade dominada pelo povo branco. Eu não reconhecia a implicação metodológica dessa suposição até o verão de 1966, quando Willie Ricks fez soar o grito do "poder negro" e Stokely Carmichael 4 se juntou a ele como o porta-voz filosófico. Contudo, bem antes disso, eu sabia, nas profundezas do meu ser, que as abordagens teológicas europeia e norte-americana não tratavam das questões que surgiam de minha experiência (CONE, 1985, p. 13).

Já sobre a sua formação teológica, centrada em cânones ocidentais, James Cone relata que dedicou-se a estudar importantes teólogos europeus como Karl Barth, Rudolf Karl Bultmann e Paul Tillich, sendo uma trajetória intelectual comum

\footnotetext{
4 Willie Ricks (1943-), também conhecido como Mukasa Dada, e Stokely Carmichael (1941-1998) foram ativistas negros precursores do Movimento de Poder Negro. Ambos membros do Student Nonviolent Coordinating Committee (SNCC) e, posteriormente, do Partido dos Panteras Negras.
} 
daquela época. Para nossa análise, torna-se significativo aproximar a autocompreensão de Cone a respeito dessas referências ao argumento de que sua teologia negra parte das premissas que a teologia contemporânea lhe ofereceram, mas difere destas justamente pela dialética implicada no encontro da pessoa do/a teólogo/a com sua realidade:

Como a maioria dos estudantes de escolas e seminários de minha geração, fielmente eu estudei filosofia e teologia - desde os pré-socráticos até o existencialismo moderno, e a análise linguística, desde Justino Mártir e Orígenes até Karl Barth, Bultmann e Tillich. Eu era um especialista sobre Karl Barth e conhecia bem as implicações teológicas que formaram a sua teologia. Fiz relatórios em seminário sobre os debates de Karl Barth e Brunner, sobre o conhecimento de Deus na teologia contemporânea, sobre o programa de desmitização (sic) preconizado por Bultmann, sobre a doutrina de Deus como ser-em-si, e concluí minha formação intelectual com uma dissertação de $P h$. D. sobre a antropologia de Barth (CONE, 1985, p. 13).

Com essas premissas, após sua formação acadêmica, quando passou a ministrar aulas para estudantes negros, as implicações dessa diferença se ampliavam e exigiam de Cone a revisão de seus referenciais teóricos, que distanciavam-se da realidade da comunidade negra e a sua forma de se relacionar e entender Jesus Cristo:

Quando deixei o Garret Theological Seminary e a Northwestern University (1963) e comecei a lecionar no Philander Smith College, em Little Rock, Arkansas, tive um encontro frontal com as contradições de minha formação no Seminário quando tentei informar os estudantes negros sobre o significado do discurso teológico. O que podia possivelmente significar Karl Barth para estudantes negros que tinham vindo dos campos de algodão de Arkansas, Louisiana e Mississippi, procurando mudar a estrutura de suas vidas numa sociedade que tinha definido o negro como não-ser? Qual é o significado de Nicéia e Calcedônia para aqueles que conheciam Jesus não como uma ideia em sua cabeça a ser analisada em relação a uma ideia semelhante chamada Deus? Eles conheciam Jesus como Salvador e um amigo, como o "lírio dos vales e a brilhante estrela da manhã” (CONE, 1985, p. 13-14 - grifo do autor).

Em suma, as contradições de uma sociedade em que o racismo distinguia cristãos negros de cristãos brancos se refletiam na trajetória de vida, vivência religiosa e percurso intelectual de James Cone, marcado pelo culto da Igreja Negra e pela teologia ocidental. Foi necessário a formulação de uma teologia que emergisse da dialética entre a fé e a história e a cultura, mas, nesse caso, não a história e a cultura da Europa do século XIX e sim a história e cultura dos negros. Foi necessário relacionar as Escrituras com a condição de oprimidos dos negros para entender o que 
Jesus significava para a comunidade negra. Nesse sentido, o surgimento da TNdL representou uma guinada de perspectiva em relação à teologia e filosofia ocidentais: se a situamos na "virada hermenêutica" (GEFFRÉ, 2004) que determina a teologia contemporânea ocidental, o princípio ontológico histórico que esta assume leva a hermenêutica teológica negra a inflexões ainda mais incisivas a partir de seu lugar e condição de interpretação e narrativa. Pois, a tradição religiosa negra já fazia ela mesma uma hermenêutica da vida, por meio de sua experiência dos símbolos cristãos, sua história de opressão e luta por liberdade, tal como expressa o relato autobiográfico de James Cone. Uma teologia do negro para o negro era o desdobramento legítimo dessa experiência.

\section{O PAPEL DO TEÓLOGO E DA TEÓLOGA NEGRA}

A relação entre hermenêutica e vida fica evidente nessa compreensão de teologia, destacando a percepção de uma demanda que correlaciona a reflexividade teológica com uma função tão crítica quanto criativa. Isto é, ao tomar símbolos e narrativas cristãs para denunciar injustiças, a teologia não esgota sua tarefa, na medida em que lhe cabe promover esperança à comunidade que sofre essas injustiças. Importa, assim, perguntar: que papel deve ser realizado pelo teólogo e pela teóloga negra, uma vez que a teologia negra é indissociável da comunidade na qual ela surge e a partir da qual é interpretada e sistematizada em uma narrativa teológica?

Para James Cone, o teólogo e a teóloga negra não são apenas intelectuais. Eles devem ter uma relação orgânica com aqueles/as que estão sendo chamados/as à liberdade. Ambos devem estar comprometidos em suas causas na busca por liberdade e justiça, pois:

A teologia cristã é a linguagem acerca do caráter libertador da presença de Deus em Jesus Cristo, quando ele chama o seu povo para ser livre no mundo. A tarefa do teólogo, como membro do povo de Deus, é tornar claro aquilo que a Igreja crê e faz em relação à participação dela na obra libertadora de Deus no mundo (CONE, 1985, p. 16-17). 
A qualidade orgânica da relação da pessoa do/a teólogo/a com sua comunidade traduz-se em cinco funções com quais Cone define sua tarefa - nas quais queremos destacar a dimensão hermenêutica: exegeta, profeta, mestre, pregador e filósofo. Enquanto exegeta, o teólogo é um intérprete das Escrituras e da existência concreta. A Bíblia torna-se indispensável, mas a sua mensagem precisa estar relacionada com a existência humana e seus dilemas enfrentados em um determinado contexto histórico: "Ser um exegeta da existência significa que as Escrituras não são uma palavra abstrata, não meramente uma ideia racional. As Escrituras são a Palavra de Deus aos oprimidos e humilhados deste mundo" (CONE, 1985, p. 17): foi partindo desse princípio que Cone encontrou motivações para escrever o seu primeiro livro. Neste, ele se vale de um momento em que o movimento Black Power tornava-se expressivo em sua luta contra a opressão para realizar uma interpretação teológica desse acontecimento, que lançava novas luzes sobre a história dos negros nos Estados Unidos:

Instintivamente, usei as Escrituras como fonte primária para essa nova abordagem e perguntei: "O que a mensagem bíblica tem a ver com a revolução do poder negro?” Minha resposta é encontrada no meu primeiro livro, intitulado "Black Theology and Black Power (Seabury, 1969)" (CONE, 1985, p. 15).

É digno de nota que, para Cone, a exegese do texto clássico cristão é, ao mesmo tempo, uma hermenêutica da vida. A premissa se alinha com a definição hermenêutica de teologia de Geffré, que toma a Bíblia e a tradição teológica na sua condição de "múltiplas recepções no curso dos tempos", lembrando que estas jamais encerram uma "interpretação definitiva”, porque se dão na “correlação crítica entre a experiência cristã da primeira comunidade cristã e nossa experiência histórica de hoje" (GEFFRÉ, 2004, p. 39,40). No caso de Cone, como temos destacado, a condição histórica de ser um homem negro determinou a crítica na qual operou sua recepção e hermenêutica teológica. Uma crítica ao mesmo tempo criativa, operada em linguagem e esquema de pensamento próprios (GEFFRÉ, 2004, p. 41), dando lugar a uma teologia própria: a teologia negra.

O subjetivismo implicado nesse argumento é evitado por Cone ao recorrer impreterivelmente à noção de justiça como princípio da hermenêutica teológica. Ao definir o papel do teólogo como profeta, Cone insiste no dever de anunciar a justiça 
de Deus, deixando evidente que Deus é Deus dos oprimidos, humilhados e injustiçados. A partir de sua experiência histórica, consequentemente, sua escatologia anunciará um Deus que age na luta contra o racismo.

Como profeta, ele deve tornar claro que o evangelho de Deus implica julgamento sobre a presente ordem de injustiça. (...) revelando que Deus não é indiferente ao sofrimento e não é paciente com a crueldade e a falsidade, e que o poder e o julgamento de Deus vão criar justiça e ordem no caos (CONE, 1985, p. 17).

Como mestre, o teólogo deve instruir sobre o significado e significação da fé para a vida humana, relacionando as lutas dos apóstolos e santos à luta do momento presente. Como pregador, baseando-se na tradição da Igreja Negra, o teólogo proclama a mensagem cristã, entusiasmadamente, relacionando-a à luta pela liberdade, anunciando Jesus como o Libertador dos pobres e oprimidos. “Aqui, o teólogo reconhece o caráter apaixonado da linguagem teológica. Ela é uma linguagem de celebração e alegria de que a liberdade prometida já está presente na luta da comunidade pela libertação” (CONE, 1985, p. 17). Já enquanto filósofo, o teólogo mantêm-se intelectualmente atento em não desvincular o evangelho da dinâmica histórica, especificamente em um contexto de luta, estando aberto a outras perspectivas de pensamento. Nesse quesito, James Cone entende que a hermenêutica teológica exige a tarefa crítica em relação à própria tradição de fé, opondo-se ao fundamentalismo e favorecendo a ecumene: "Ele (o teólogo) nos previne contra o dogmatismo e fornece a base para o diálogo com outros tipos de fé" (CONE, 1985, p. 18).

Em todas as funções descritas por Cone, o teólogo deve estar comprometido com a comunidade negra e com o evangelho no contexto de luta contra a opressão:

A fim de fazer teologia daquele ponto de vista, ele deve fazer perguntas corretas e em seguida ir às fontes certas para as respostas. As perguntas corretas são sempre relacionadas com a questão básica: $O$ que o evangelho tem a ver com os oprimidos da terra e sua luta pela libertação? Qualquer teólogo que falhe em colocar essa questão, no centro de sua obra, ignora a essência do evangelho (CONE, 1985, p. 18).

A ideia de perceber perguntas corretas e correlacioná-las às fontes que fornecerão as devidas respostas remete ao entendimento de Paul Tillich, quando define na introdução de sua Teologia sistemática: "A teologia, como função da igreja 
cristã, deve servir às necessidades desta igreja. Um sistema teológico deve satisfazer duas necessidades básicas: a afirmação da verdade da mensagem cristã e a interpretação desta verdade para cada nova geração” (TILLICH, 2005, p. 21). Daí o princípio hermenêutico da teologia, que "oscila entre dois pólos: a verdade eterna de seu fundamento e a situação temporal em que essa verdade eterna deve ser recebida” (Ibid., p. 21). Com esse critério, Tillich insiste na necessidade de uma adequada compreensão do que seja a "situação" e seu papel constitutivo na teologia:5

A "situação", como um dos pólos do todo trabalho teológico, não se refere ao estado psicológico ou sociológico em que vivem os indivíduos ou grupos. Ela se refere às formas cientificas e artísticas, econômicas, políticas e éticas em que se expressam sua interpretação da existência. A "situação", à qual a teologia deve falar com relevância, não é a situação do indivíduo como indivíduo e não é a situação do grupo como grupo. (...) A "situação" que a teologia deve considerar é a interpretação criativa da existência tal como se realiza em todos os períodos da história, sob todos os tipos de condições psicológicas e sociológicas (TILLICH, 2005, p. 21-22).

Poderíamos nos perguntar se temos aqui um princípio crítico à teologia negra (como teologia "situada" em um grupo como grupo, a comunidade negra, histórica e sociologicamente definida) ou, antes, se a TNdL implica numa crítica à pressupostos da teologia de Tillich, especialmente com respeito à compreensão de história e o modo como a escatologia se desdobra numa práxis teológica. Em sua análise da Teologia sistemática de Tillich sob o foco da Escatologia e teologia da ação, Etienne Higuet (2017) conclui, em um primeiro momento, que o tema escatológico, presente de modo axial na teologia tillichiana, aparentemente "desagua numa práxis libertadora de todos os setores da vida humana", especialmente em função "de sua concepção histórica - isto é, dialética - da história” (HIGUET, 2017, p. 61). Contudo, sua crítica se dá em razão de um romantismo político que, embora tenha sido por ele mesmo criticado em seus escritos políticos das décadas de 1920-30, acaba por determinar sua visão da história por um "mito de origem", reduzindo-a um "desenvolvimento das potencialidades presentes na essência do ser humano" (HIGUET, 2017, p. 63). Nestes termos, a escatologia de Tillich contraria "uma

\footnotetext{
5 Tillich aqui desenvolve uma crítica relevante ao fundamentalismo: o fato de ter sido acolhido nos Estados Unidos, na década de 1950, quando Tillich escrevia sua obra, o torna uma "resposta correta" teologicamente? Se ainda hoje o fundamentalismo tem tamanha recepção em diferentes contextos, isso indica uma "pertinência teológica"? Mas que "perguntas" o fundamentalismo pretende responder? Qual é o papel do pólo "situação" em seu discurso? Recorrendo a citação acima de Cone, o que torna então "correta" a percepção da pergunta que o/a teológo/a pretende responder?
} 
concepção bíblica e singularmente profética centrada sobre a novidade e sobre o futuro históricos”, cuja implicação, segundo Higuet, é a impossibilidade de uma verdadeira práxis, que necessariamente bebe da fonte profética bíblica. Em síntese, a crítica de Higuet, valendo-se de argumento de Mircea Eliade, se dá nas seguintes palavras: "Na medida em que aparece o desejo de apagar as ambiguidades para reencontrar o acesso à estrutura essencial, a escatologia aparece em primeiro lugar como retorno à protologia, como 'nostalgia da origem"” (HIGUET, 2017, p. 65).

Neste ponto, portanto, identificamos um dos distanciamentos entre a teologia negra de Cone e seus referenciais, sublinhando que isso se dá pelo modo como a realidade do/a teólogo/a informa a teologia que este/a desenvolve. Para Cone, não há dúvida quanto ao critério de "justiça" que define a pertinência histórica e social da teologia em relação "aos oprimidos da terra e sua luta pela libertação”. A concepção tillichiana da “situação" como pólo hermenêutico da teologia, por sua vez, lança a indagação que podemos aprofundar em Cone, com respeito a seus pressupostos em relação à história e à cultura, na linha da crítica que Higuet faz à Tillich.

\section{AS FONTES DA TEOLOGIA NEGRA}

Em relação às fontes para a elaboração de uma teologia negra, James Cone não nega as Escrituras e a tradição cristã (ocidental), mas não limita-se a elas, além de contextualizá-las. Para ele, as fontes da teologia negra devem incluir a história e a cultura dos oprimidos, que, no contexto norte-americano, são os negros, indígenas, mestiços e asiáticos. Significativo notar que James Cone não faz menção às mulheres, cuja experiência e condição histórica particular, mais tarde, daria lugar a uma hermenêutica teológica própria, legitimada pelas mesmas premissas, mas desde o corpo e perspectiva da mulher negra. ${ }^{6}$

Ao negar a universalidade da teologia tradicional euro-norte-americana, como vimos acima, James Cone defende a necessidade de buscar no evangelho respostas a perguntas da realidade concreta em um contexto/comunidade sociopolítico específico. Para isso, as fontes da teologia, necessariamente, deveriam privilegiar a experiência de vida, a história e a cultura dos negros, incluindo a apropriação criativa

\footnotetext{
${ }^{6}$ Citamos como exemplos desta perspectiva os textos:: Teologia negra e mulher negra (1979) e White Women's Christ and Black Women's Jesus (1990), de Jacquelyn Grant; e The Color of Feminism: Or Speaking the Black Woman's Tongue (1986) e Womanist Theology. Black Women's Voices (1987), de Delores Williams.
} 
da tradição cristã nas comunidades negras. A “autoridade orgânica” destas fontes, em relação à realidade para a qual o evangelho era anunciado, as tornam indispensáveis para a TNdL.

Com isso, torna-se necessário para o teólogo negro compreender como a comunidade negra relaciona a sua história e a sua cultura com a fé em Jesus Cristo. Para Cone, obviamente, essa relação se dá em uma perspectiva distinta da dos europeus e dos brancos norte-americanos. Por isso, a tradição teológica clássica é insuficiente para compreender a religiosidade cristã negra. Cone defende que os métodos de análises devem ser originados a partir das próprias fontes para fazer jus ao pensamento negro. Já notamos aqui que as fontes, imbricadas na história e cultura negra, geram a necessidade de uma epistemologia na perspectiva do negro.

As fontes que James Cone destaca são: os sermões, as orações, cânticos, e elementos da experiência do negro para além da igreja como os contos, músicas seculares e os blues e os relatos pessoais.

\subsection{Sermão}

Ao tratar sobre o sermão, enquanto um evento litúrgico da Igreja Negra, James Cone alerta para uma distinção entre palavras do texto e a Palavra revelada no texto. "A Palavra é mais do que palavras sobre Deus. A Palavra de Deus é um acontecimento poético, evocação de uma realidade indescritível na vida do povo" (CONE, 1985, p. 27-28). A Palavra é mais sentida do que racionalizada em bases teóricas brancas e acadêmicas acerca do evangelho. O evangelho é correlacionado com a busca da comunidade negra por liberdade. Portanto, "Se o evangelho significa liberdade, então a liberdade revelada nesse evangelho deve também ser revelada no evento da proclamação" (CONE, 1985, p. 28). Desse modo, a Palavra expressa-se no ritmo e nas emoções da linguagem. Para Cone, quando o povo sente e confirma a veracidade da Palavra proclamada no sermão, é um sinal da presença do Espírito no meio do povo, que responde com ressonantes "améns". O sermão está intimamente ligado com as condições de existência da comunidade negra, "O sermão negro resulta da totalidade da existência do povo - sua dor e alegria, aflição e êxtase" (CONE, 1985, p. 28). 


\subsection{Oração}

Para James Cone, as orações dos negros não são iguais às dos brancos. Afirma que mesmo em situação de escravidão, sendo obrigado pelo senhor a cultuar o cristianismo, "o escravo transcendia as limitações da servidão e afirmava um sistema de valores religiosos que diferia do de seu senhor" (CONE, 1985, p. 29). Essa distinção evidenciava a afirmação da identidade negra na oração, o que leva James Cone a propor que o teólogo negro deve refletir sobre a Palavra da oração como revelada na afirmação da identidade dos negros. Em uma situação de opressão, a oração do negro revela a afirmação da identidade negra em busca da liberdade de ser o que se é: "Deus é o Espírito de Jesus que guia e move o povo negro em sua luta para ser aquilo que deve ser por criação" (CONE, 1985, p. 30).

4.3 Cântico (spirituals e cânticos do evangelho)

Cone aponta que, assim como o sermão e a oração, os spirituals e cânticos do evangelho revelam que a verdade da religião dos negros não se limita à literalidade das palavras. A verdade se revela no modo como a linguagem é expressada, entusiasticamente, apaixonada, com gritos, gemidos, nas cantorias, na entonação e qualidade tonal corretas, onde ambiguamente expressam a dor e a alegria, a existência trágica dos negros e a sua resistência em não aceitar essa trágica condição.

Alguns dos exemplos sugeridos por James Cone aos teólogos negros para terem acesso a essas fontes são: livros que se dedicaram a estudar e compilar sermões, orações e cânticos; o cântico negro na própria igreja negra (o que seria um estudo empírico); gravações de artistas como Mahalia Jackson, James Cleveland, Clara Ward e Paul Robeson, e o álbum (na época recente) “Amazing Grace” de Aretha Franklin.

A música "Amazing Grace", cantada por artistas como Aretha Franklin e Mahalia Jackson, é um exemplo de que o que importava para James Cone não era necessariamente a autoria dos cânticos, mas o modo como os negros se apropriavam deles. A citada canção foi originalmente composta por um ex-comerciante de escravos. Porém, James Cone percebe a apropriação e ressignificação que os negros dão à canção quando cantada em um contexto de opressão social, política e cultural, 
fazendo referência à presença de Deus para a superação dessa situação:

(...) quando os filhos e filhas de escravos negros o cantavam, "Maravilhosa Graça" recebia a infusão da força e do significado negros. Para os negros de Bearden, os "perigos, lutas e armadilhas" se referiam à sua luta diária pela sobrevivência, aos altos e baixos da existência negra, e à tentativa de tomar posse de uma melodia de liberdade numa situação extrema de opressão. "Maravilhosa Graça" foi o milagre da sobrevivência, porque é difícil explicar como nós fizemos, através da escravidão, a reconstrução e a luta contra a opressão no século XX. Os negros de Bearden diziam: "Deve ter sido a graça de Deus!" (CONE, 1985, p. 13).

\subsection{A experiência "secular"}

Embora já tenhamos citado o sermão, a oração e o cântico como fontes da teologia negra propostas por James Cone, o referido autor não limita as fontes à experiência ligada à Igreja Negra. Cone propõe que as fontes da teologia negra também incluam a experiência negra dita secular. Porém, Cone faz questão de esclarecer que o que em sua teologia negra se entende por secular não significa a distinção ocidental entre o sagrado e o profano, pois, embora essa experiência negra não esteja ligada à Igreja, ao cristianismo e nem se refira a Deus, ela não é necessariamente antirreligiosa ou não-religiosa.

Esse lado da experiência dos negros é secular, apenas enquanto é terreno e raramente usa Deus ou o cristianismo como os principais símbolos de suas esperanças e sonhos. É sagrado, porque é formado da mesma comunidade histórica como a experiência da igreja, e representa assim a tentativa do povo de formar a vida e vivê-la de acordo com seus sonhos e aspirações (CONE, 1985, p. 33).

Como exemplos dessa experiência "secular", Cone cita os contos, músicas seculares e os blues e os relatos pessoais, identificando nessas expressões culturais o mesmo tema da sobrevivência e libertação que é encontrada no sermão, oração e cântico, expressando por um lado a libertação de Deus dos injustiçados e por outro lado a transcendência sobre as negações históricas. $\mathrm{O}$ autor ainda destaca a literatura negra, particularmente a poesia ligada à Renascença do Harlem (das décadas de 20 e 30) e seus sucessores, destacando poemas de Claude McKay7 e Amiri Baraka ${ }^{8}$.

7 Claude McKay (1889-1948) foi um poeta negro jamaicano, radicado nos Estados Unidos. Foi um personagem importante na configuração do movimento artístico negro conhecido como Harlem Renaissance.

8 Amiri Baraka (1934-2014) foi um poeta, dramaturgo e ativista negro norte-americano. Foi um dos líderes do Black Arts Moviment. 


\section{CONSIDERAÇÕES FINAIS}

A partir desse breve estudo de parte da obra O Deus dos oprimidos de James Cone, situando-a na "virada hermenêutica" (GEFFRÉ, 2004), podemos considerar que a Teologia Negra de James Cone não apenas constrói uma narrativa a partir de um novo sujeito teológico, no caso, na perspectiva do negro, distinguindo-se da tradição ocidental, como também preocupa-se em consolidar métodos e epistemologia específicos para essa teologia.

James Cone coloca a sua própria experiência de vida, enquanto negro em uma sociedade racista dominada por brancos, como um elemento fundamental para a sua reflexão teológica. Pois, para ele, não há neutralidade na interpretação que se faz das Escrituras, nem há teologia que não revele particularidades de seu tempo e contexto social, político e cultural, sendo necessário para a Teologia Negra assumir um pensamento que correlacione a mensagem cristã com a história e cultura dos negros em sua busca por liberdade e justiça. Para isso, é necessário que o teólogo negro esteja comprometido com a comunidade negra, exercendo as funções de exegeta, profeta, mestre, pregador e filósofo, mergulhando na cultura negra, religiosa e/ou "secular", considerando-a como a fonte fundamental da reflexão teológica para compreender a sua relação com a fé. Isto porque, em síntese, o cristianismo dos negros é diferente do cristianismo dos brancos. No entanto, o cristianismo essencial é aquele dos humilhados, dos empobrecidos, dos injustiçados, que cultivam a esperança, os sonhos, o anseio por justiça e liberdade. Pois, para Cone, Deus é o Deus dos oprimidos.

\section{REFERÊNCIAS}

ALVES, Rubem. Por uma teologia da libertação. São Paulo: Fonte Editorial, 2012.

AMIRI BARAKA. Bio Graphy. Disponível em:

<http://www.amiribaraka.com/bio.html>. Acesso em: 16 set. 2018.

BRITANNICA ESCOLA. Movimento Pelos Direitos Civis. Disponível em: <https://escola.britannica.com.br/levels/fundamental/article/Movimento-pelosDireitos-Civis/480991>. Acesso em: 16 set. 2018.

CIVIL RIGHTS DIGITAL LIBRARY. Ricks, Willie Floyd, 1943-. Disponível em: < 
http://crdl.usg.edu/people/r/ricks_willie_floyd_1943/?Welcome>. Acesso em: 16 set. 2018.

CIVIL RIGHTS DIGITAL LIBRARY. Stokely Carmichael. Disponível em: <http:/ / crdl.usg.edu/cgi/crdl? skipfacets $=1$ \&numrecs $=25$ \&action=query\&term_a=st okely_carmichael\&index_a=kw\&_cc=1>. Acesso em: 16 set. 2018.

CONE, James H. A Black Theology of Liberation. Nova York: Lippincott, 1970.

CONE, James H. Black theology. In: RICHARDSON, A.; BOWDEN, J. (Ed.). The Westminster dictionary of christian theology. Philadelphia: The Westminster Press, 1983, p. 72-75.

CONE, James H. Black Theology and Black Power. Nova York: Seabury Press, 1969.

CONE, James H. O Deus dos oprimidos. Trad. Josué Xavier. São Paulo: Paulinas, 1985 .

DILTHEY, Whilhelm. O surgimento da hermenêutica (1900). Trad. Eduardo Gross. Numen, v.2, n.1, 1999, p. 11-32.

DUNAWAY, Filipe. A Teologia Negra: uma introdução. Disponível em: <http://www2.teologica.br/webportal/home/images/stories/enade/teologia_negra. pdf $>$. Acesso em: 15 jul. 2017.

GADAMER, Hans-Georg. Verdade e método. 3.ed. Trad. Flávio Paulo Meurer. Enio Paulo Giachini. Petrópolis: Vozes, 1999.

GEFFRÉ, Claude. Crer e interpretar: a virada hermenêutica da teologia. Trad. Lúcia M. Endlich. Petrópolis: Vozes, 2004.

GIBELlini, Rosino. A Teologia do século XX. Trad. João Paixão Netto. São Paulo: Loyola, 1998. Capítulos IV, XII e XIII.

GRANT, Jacquelyn. Elementos e pressupostos da reflexão teológica a partir das comunidades negras - Estados Unidos. In: SILVA, Antônio Aparecido da. (Org.). Teologia Afro-americana: II Consulta Ecumênica de Teologia e Culturas Afroamericana e Caribenha. São Paulo: Paulus, 1997.

GRANT, Jacquelyn. Teologia Negra e a Mulher Negra. In: CONE, James H,; WILMORE, Gayraud S. (orgs.). Teologia Negra. Trad. Euclides Carneiro da Silva. São Paulo: Paulinas, 1986.

GRANT, Jacquelyn. White Women's Christ and Black Woman's Jesus. Atlanta: Scholars Press, 1990.

GROSS, Eduardo. Hermenêutica e religião a partir de Paul Ricoeur. Numen, v.2, n.1, 1999, p. 33-49. 
GUIMARÃES, L. E. A teologia da libertação sob o viés protestante. 2012. (Apresentação de Trabalho/Comunicação). Disponível em: <http://www.uel.br/eventos/sepech/arqtxt/PDF/luizeguimaraes.pdf>. Acesso em: 29 set. 2018.

GUTIÉRREZ, Gustavo. Teologia da libertação. Trad. Jorge Soares. Petrópolis: Vozes, 1975.

HIGUET, Etienne. A teologia de Paul Tillich: utopia, esperança e socialismo. São Paulo: Fonte Editorial, 2017.

PÁDUA, Jorge Hage. Teologia Negra da Libertação: Expressão teológica dos oprimidos na América Latina. Estudos Teológicos, v. 39, n. 2, p. 143-146, 1999. Disponível em:

$<$ http://periodicos.est.edu.br/index.php/estudos_teologicos/article/download/715/ 650.>. Acesso em: 16 jul. 2017.

POETS.ORG. Claude McKay. Disponível em:

<https://www.poets.org/poetsorg/poet/claude-mckay>. Acesso em: 16 set. 2018.

REVISTA PANORAMA. Morre aos 79 anos o polêmico escritor e ativista Amiri Baraka. Disponível em:

<http://www.panorama.com.br/index.php?option=com_k2\&view=item\&id $=15797 \%$ 3Amorre-aos-79-anos-o-pol\%C3\%AAmico-escritor-e-ativista-amiribaraka\&Itemid=24>. Acesso em: 16 set. 2018.

RICOEUR, Paul. Interpretação e ideologias. Rio de Janeiro, RJ: Francisco Alves, 1977.

SANTANA, Thayná Menezes. Racismo e Identidade Nacional: comparando Estados Unidos e Brasil. 2017.36 f. Monografia (Ciência Política) - Universidade de Brasília: Brasília, 2017. Cap. 2.

TILLICH, Paul. Teologia sistemática 5.ed.rev. Trad. Getúlio Bertelli; Geraldo Korndörfer. Rev. Ênio R. Mueller. São Leopoldo: Sinodal. EST, 2005.

WILLIANS, Delores. The Color of Feminism: Or Speaking the Black Woman's Tongue. The Journal of Religious Thougt. vol. 43, n. 1, spring-summer, 1986, pp. 42-58.

WILLIAMS, Delores. Womanist Theology. Black Women's Voices. In: CHRIST, C; PLASKOW, J. (orgs.). Weaving the Visions. New Patterns in Feminist Spiritulity. San Francisco: Harper and Row, 1989, pp. 179-186.

Recebido em: 30.09 .2018 Aprovado em: 24.12.2018 